New Exchanges.

Proceedings de la Société Industrielle de Rouen.

\title{
Feritere.
}

Presented by Wm. M. Habirshaw :

Mineralogical Cabinet.

Purchased by the Society:

Book-case.

$$
\begin{gathered}
\text { New Exchasges Received } \\
\text { During the Months of March and April. }
\end{gathered}
$$

AMERICAN.

The Plumber and Sanitary Engineer.

EN(ILISH.

The Pharmaceutical Journal and Transactions.

Journal of the Chemical Society.

FRENCH.

Proceedings de la Société d'Encouragement pour l'Industrie Nationale.

Bulletin de la Société Industrielle de Mulhouse.

Bulletin de la Société Industrielle d'Amiens.

Report ox the Berzelius Medal, Presented to the American Chemical Society hy Dr. Hanbury Smith.

On the 17th of last April, the American Chemical Society celebrated its third anniversary by a dinner, which took place at Sieghürtner's Restaurant. At the head of the table was Prof. T. Sterry Hunt, the President of the Society, having on his right Prof. Silliman, of Yale, and on his left P'rof. Leeds, of the Stevens' Institute.

In his address to the assembled chemists, Dr. Hunt reminded them that in this year, 1879, occurs, on the 20th of August, the one hundredth anniversary of the birth of Berzelius. He referred to the great Swedish chemist and to the eminent services he had rendered to science. 
During the evening a messenger came from Dr. Hanbury Smith, with a very neat morocco case containing a beautiful brouze medal of Berzelius, and the following letter addressed to me:

\section{The Rockingham,}

My DEAR SIR :

Broadway and 56th St.

I am very much disappointed to be kept away, by a fit of lumbago, from a gathering I had set my heart on enjoying.

I send hereby a medal I desire to present to the Society, and beg you to be my representative in doing so. It was struck by the Swedish Medical Society to the memory of Berzelius, who then had been the last survivor of the founders of that Society. The likeness is admirable.

Dr. Hunt will, no doubt, allude to the characteristics of Beqrzelius, his passion for order, and his early prophetic conviction that the chemical world was governed by laws of measure, weight and number. Again, his remark : "I feel an ardent longing to strengthen the union between my soul and the un. changeable laws of nature, and for this object will I labor till death stops further progress on this earth." And this object he never lost sight of. Next, his independence of charicter, which, perhaps, sometimes caused him to hold fast to convictions no longer impregnable. His gentleness and bonhommic. Hence, the great pain which the treatment of Davy, on two occasions, caused him, and the little unpleasuntness with Liebig about lactic acid. His content with a very moderate income must not be forgotten, joined to the fact that many pupils who worked in nis laboratory, not only paid him nothing, but had free use of his laboratory, \&c. He lived for others-he asked nothing for himself-and the world is much better for his having lived in it.

Yours, in respect for his memory,

(Signed)

HANBURY SMITh.

This letter possesses remarkable interest from the fact that Dr. Hanbury Smith, who studied chemistry and medicine in Sweden, and lived in that country for many years, was personally acquainted with Berzelius, whom he saw almost daily for several years.

The medal presented to the American Chemical Society is a beautiful work of art. Its diameter is $2 \frac{1}{4}$ inches. The face of Berzelius is finely moulded in bold relief, and is full of expression. On the reverse side are represented Medicine, as a sitting female figure, and Chemistry, as a young man who pours a liquid from a flask into a cup held by the female figure. The workmanship is in the best style of numismatic art.

On account of the beauty of this medal, and of the interest which attaches to it in this, the centennial year of the birth of Berzelius, I would suggest that copies of it be taken for the benefit of such members of this Society as desire to subscribe for these copies. In this connection, I am happy to state that I have been so fortunate as to 